\title{
PETERNAKAN KAMBING PERANAKAN ETAWA DI KABUPATEN BANTUL
}

\author{
Hera Wasiati' ${ }^{1)}$, Edi Faizal' ${ }^{2)}$ \\ ${ }^{1,2)}$ Manajemen Informatika STMIK Akakom Yogyakarta \\ e-mail : hera@ akakom.ac.id ${ }^{1}$, edifaizal@akakom.ac.id ${ }^{2}$
}

\begin{abstract}
Abstrak
Peternakan kambing peranakan etawa (PE) saat ini berkembang sangat pesat karena banyak hasil yang dapat diperoleh. Beberapa hasil diantaranya berupa penjualan induk, anakkan dan susu. Tambahan lain adalah hasil pengolahan kotoran kambing (inthil) menjadi pupuk organik. Penyediaan pakan yang baik dan dalam jumlah yang cukup perlu dilakukanuntuk meningkatkan kualitas kambing, susu dan anakan yang dihasilkan. Supaya terus tersedianya pakan yang berkualitas maka diperlukan pengetahuan untuk pembuatan pakan kambing fermentasi yang berkualitas baik dan dapat bertahan lama. Berbagai macam olahan susu kambing dapat dihasilkan seperti susu murni yang dikemas dalam botol maupun susu bubuk beraneka rasa. Limbah kotoran kambing, baik berupa limbah padat (inthil) maupun limbah cair (urine) jika dikelola dengan baik akan memberikan nilai tambah ekonomi. Selain itu diperlukan juga pengetehuan tentang manajemen pengelolaan dan teknik pemasaran yang baik untuk mendapatkan keuntungan yang maksimal. Penggunaan teknologi informasi (e-commerce) akan dapat memperluas jangkaun pemasaran produk-produk kambing etawa. Kegiatan IbM ini melibatkan dua mitra Kelompok Peternak Kambing Etawa di Banguntapan, Bantul yaitu "Kelompok PE Jaya" dan "Kelompok PE Makmur". Kegiatan yang telah berhasil dilaksanakan untuk mengatasi permasalahan yang dialami mitra yaitu (1) penerapan teknologi tepat guna dalam pengolahan pakan alternatif/ buatan (fermentasi), (2) penerapan teknologi tepat guna untuk pengolahan limbah padat menjadi pupuk organik, (3) proses pengolahan susu aneka rasa, (4) peningkatan pengetahuan dalam penanganan anak kambing baru lahir dan (5) perbaikan sistem manajemen usaha dan pemasaran dengan memanfaatkan media online.
\end{abstract}

Kata Kunci : dampak,limbah, lingkungan, rumah potong hewan

\section{PENDAHULUAN}

Kambing etawa atau di Indonesia lebih dikenal sebagai kembing Peranakan Etawa (PE) memiliki tempat tersendiri dikalangan peternak. Perkembangan dan minat dari peternak dalam membudidayakan kambing etawa meningkat pesat dari tahun ke tahun. Menurut produk yang dihasilkan, kambing PE dikelompokkan menjadi 4 yaitu penghasil daging (tipe pedaging), penghasil susu (tipe perah), penghasil bulu (tipe bulu/mohair/cashmere), dan penghasil daging dan susu.

Beberapa karakter penting dari kambing PE antara lain, bentuk muka cembung, telinga relatif panjang $(18-30 \mathrm{~cm})$ dan terkulai. Jantan dan betina bertanduk pendek. Warna bulu bervariasi dari kream sampai hitam. Bulu pada bagian paha belakang, leher dan pundak lebih tebal dan lebih panjang daripada bagian lainnya. Warna putih dengan belang hitam atau belang coklat cukup dominan. Tinggi badan untuk jantan 70-100 cm, dengan berat badan dewasa mencapai 40-80 kg untuk jantan dan 30-50 kg untuk betina.

Peternakan kambing peranakan etawa (PE) saat ini berkembang sangat pesat karna banyak hasil yang dapat diperoleh. Beberapa hasil diantaranya berupa penjualan induk, anakkan dan susu. Tambahan lain adalah hasil pengolahan kotoran kambing (inthil) menjadi pupuk organik. Saat ini yang sedang booming dipasaran adalah penjualan susu kambing etawa.

Beternak kambing etawa perlu juga didukung oleh penyediaan pakan yang baik dan dalam jumlah yang cukup. Pakan yang baik dan cukup akan meningkatkan kualitas kambing, susu dan anakan yang dihasilkan. Supaya terus tersedianya pakan yang berkualitas maka diperlukan pengetahuan untuk pembuatan pakan kambing fermentasi yang berkualitas baik dan dapat bertahan lama. Selain itu diperlukan juga pengetehuan tentang manajemen pengelolaan dan teknik pemasaran yang baik untuk mendapatkan keuntungan yang maksimal. 
Penggunaan teknologi informasi (e-commerce) akan dapat memperluas jangkaun pemasaran produkproduk kambing etawa.

Berbagai alasan tersebut menjadikan kambing jenis peranakan etawa (PE) saat ini menjadi primadona yang berkembang di kalangan peternak kambing, khususnya di Kabupaten Bantul. Dalam melakukan budidaya kambing etawa masyarakat membentuk suatu kelompok peternak. Seiring dengan digalakkanya usaha pemberdayaan masyarakat untuk peningkatan ekonomi, maka kegiatan usaha kerakyatan mendapat perhatian serius dari pemeritah Kabupaten Bantul.

Saat ini di Kabupaten Bantul banyak tumbuh kelompok-kelompok usaha khususnya bidang pertanian dan peternakan. Diantara kelompok peternak kambing peranakan etawah (PE) yang berada di kabupaten Bantul adalah "Kelompok PE Jaya dusun Modalan" dan "Kelompok PE Makmur dusun Pringgolayan" yang menjadi mitra dalam kegiatan Ipteks ini. Kedua kelompok mitra tersebut berada di Kecamatan Banguntapan. Jarak Ibukota Kecamatan ke pusat pemerintahan Kabupaten Bantul adalah 15 $\mathrm{Km}$ dan berbatasan langsung dengan Kota Yogyakarta.

Kepedulian pemerintah Kabupaten Bantul dalam mengembangkan peternakan diwujudkan melalui program padat karya produktif dibawah koordinasi Dinas Tenaga Kerja dan Transmigrasi (DISNAKERTRAN). Bantuan yang diberikan berupa pembangunan kandang semi permanen. Masingmasing kelompok menempati kandang seluas $60 \mathrm{M}$ persegi

Motivasi anggota kedua kelompok mitra masih rendah, manajemen usaha serta jiwa kewirausahaan masih belum terbentuk. Kurangnya pengetahuan peternak dalam manajemen pakan dan reproduksi, termasuk perawatan anakan (cempe) merupakan masalah utama kelompok yang harus menjadi perhatian, disamping permasalahan akses terhadap modal dan pemasaran. Baik untuk peningkatan jumlah populasi, maupun untuk pengadaan alat-alat pengolah dan penyimpanan hasil produksi.

Sampai saat ini, susu hasil perahan kedua kelompok sama sekali tanpa pengolahan (raw material), sehingga masih belum banyak dijual kepada masyarakat, melainkan hanya untuk konsumsi sendiri. Pemerahan susu yang dilakukan masih menggunakan cara sederhana dan menggunakan alat seadanya. Kualiatas dan kuantitas susu hasil perahan belum mendapat perhatian =yang serius dari anggota kelompok.

Jika dikelola dengan baik, susu kambing etawa mempunyai banyak kelebihan dibanding susu ternak lainnya. Susu kambing memiliki keunggulan tersendiri sebab mengandung nilai gizi yang tinggi yaitu protein $3.4 \%$, lemak $4.1 \%$, karbohidrat $5.2 \%$, kalsium $120 \mathrm{mg} / 100$ gram, fosfor $135 \mathrm{mg} / 100$ gram dan berbagai macam vitamin. Susu kambing mengandung protein lebih tinggi dibanding susu sapi, merupakan sumber kalsium, fosfor dan vitamin yang sangat diperlukan untuk pertumbuhan untuk usia muda dan mencegah osteoporosis pada manula. Bagi sebagian masyarakat, susu kambing dipercaya dapat meningkatkan vitalitas dan mengobati berbagai macam penyakit karena kandungan gizinya yang lengkap terutama asam amino, vitamin dan mineral. Hasil beberapa kajian pustaka ditemukan bahwa susu kambing dapat menyembuhkan berbagai penyakit diantaranya asma, kolesterol tinggi, asam urat dan osteoporosis serta dapat menggantikan fungsi ASI.

Jumlah produksi susu yang diperoleh kedua kelompok per ekor umumnya hanya antara 0,7 liter sampai 1 liter perhari. Penggunaan metode terapi pada kambing dan formula pakan yang tepat dapat meningkatkan produksi sampai dengan 3,8 liter perhari per ekor kambing. Jika harga rata-rata susu kambing adalah $\mathrm{Rp}$ 15.000/liter, maka terdapat peningkatan penghasilan peternak yang cukup signifikan dari produksi susu.

Kotoran kambing yang dihasilkan kedua kelompok, baik berupa limbah padat (inthil) maupun limbah cair (urine) belum diolah dengan baik. Urine dibuang ke sungai melalui saluran yang sudah disediakan dan belum diolah dan dimanfaatkan sebagai pupuk cair. Sedangkan limbah padat (inthil) hanya dikumpulkan dan dikemas dalam karung. Jika ada petani yang membutuhkan, kelompok mitra akan menjual secara borongan dengan harga yang sangat murah yaitu hanya 70-100 ribu rupiah per mobil (2530 karung). Keadaan kelompok yang demikian membawa dampak pada pencemaran lingkungan yaitu air dan bau yang mengganggu kesehatan. Teknik fermentasi menjadi pupuk cair dan pupuk 
organik padat akan memberikan nilai tambah ekonomi.

Kambing peranakan etawa (PE) cocok hidup di daerah tropis, dengan tatalaksana yang baik mampu melahirkan sampai 2 kali setahun, atau paling minim 3 kali dalam 2 tahun. Jumlah anak sekali kelahiran 13 ekor. Produksi setinggi ini akan dapat dicapai secara maksimal bila kebutuhan pakannya terpenuhi, disamping hijauan juga dibutuhkan pakan konsentrat seperti Polar, bungkil, gula Jawa, buah nangka (hijau), kulit kedelai, bekatul, ampas tahu, jagung, ketela dan singkong. Disamping itu kambing Etawa juga memerlukan pakan penyedap dengan menambahkan garam dapur dan tepung tulang.

Tingkat kelahiran ternak dari kedua kelompok mitra masih rendah karena pengelolaan reproduksinya kurang maksimal. Kelompok ternak kambing PE Jaya dan PE Makmur melakukan cara yang sama dalam hal pemberian pakan. Pakan utama yang digunakan masih mengandalkan hijauan ramban dari tanaman pekarangan/kebun. Pakan yang diberikan berupa yaitu daun kaliandra, daun resede, daun wilodo, daun kates atau buahnya, daun senu, daun sengon laut, daun nangka, daun mindi daun jipang atau buahnya bahkan terkadang dari diberikan kulit singkong. Daun-daunan dicacah dulu sebelum diberikan pada kambing, proses pencacahan dengan menggunakan parang supaya dapat mencacah ranting-ranting pohon. Dengan cara seperti ini masih terdapat ranting pohon yang tidak tercacah sempuna sehingga tidak termakan oleh kambing. Jika musim penghujan berbagai macam dedaunan yang digunakan untuk pakan kambing banyak tersedia. Pada saat musim kemarau daun-daunan yang dibutuhkan untuk pakan kambing sangat terbatas, sehingga peternak harus membeli daun-daunan untuk pakan kambing. Dengan demikian pengeluaran peternak semakin besar dan dapat mengganggu produksi susu jika daun-daun pakan kambing tidak tersedia.

Melihat betapa kompleksnya permasalahan yang dihadapi mitra dan keterbatasan dari tim pelaksana Ipteks, maka prioritas permasalahan yang akan diatasi melalui kegiatan Ipteks ini adalah 1) penerapan teknologi tepat guna dalam pengolahan pakan alternatif/ buatan (fermentasi), 2) penerapan teknologi tepat guna untuk pengolahan limbah padat menjadi pupuk organik, 3) pengolahan susu aneka rasa, 4) peningkatan pengetahuan dalam penanganan anak kambing baru lahir, dan 5) perbaikan sistem manajemen usaha dan pemasaran.

\section{METODE KEGIATAN}

Informasi mengenai beberapa permasalahan yang dihadapi oleh Kelompok Peternak Kambing Etawa PE Jaya dan Kelompok Peternak Kambing Etawa PE Makmur tersebut tentunya harus sesegera mungkin untuk diatasi sebagai salah satu solusi pengembangan usaha kecil dan menengah. Melalui program kegiatan Ipteks ini dan berdasarkan analisis kebutuhan yang telah dilaksanakan, tim pengabdi menawarkan solusi terhadap permasalahan tersebut dengan sentuhan Ipteks sebagaimana diuraikan pada bagian sebelumnya. Skema pelaksanaan kegiatan program Ipteks yang akan dilakukan bersama kedua mita difokuskan pada dua bidang, yaitu penerapan teknologi tepat guna dan perbaikan manajemen usaha, sebagaimana disajikan pada Gambar 1.

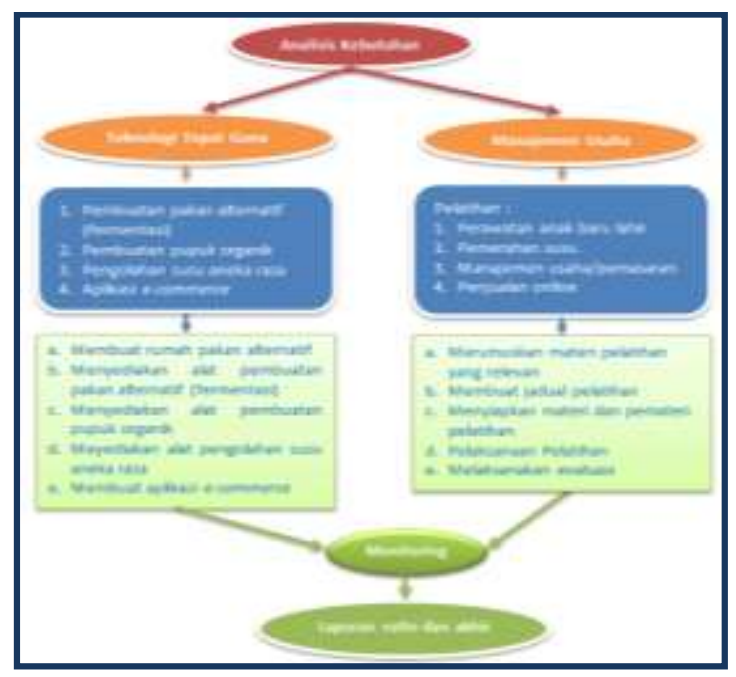

Gambar 1. Skema pelaksanaan

Rencana penerapan teknologi tepat guna meliputi teknik pembuatan pakan alternatif/buatan (fermentasi), teknik pembuatan pupuk organik, teknik pengolahan susu aneka rasa serta aplikasi e-commerce. Sedangkan kegiatan perbaiakan manajemen usaha diwujudkan dalam bentuk pelatihan. Pelatihan yang direncanakan adalah pelatihan perawatan anak baru lahir (cempe), pelatihan pemerahan susu, pelatihan manajemen usaha dan pelatihan penjualan online melalui website (e-commerce). 


\section{HASIL DAN PEMBAHASAN}

Kegiatan pengabdian diawalai dengan koordinasi Tim IbM dilaksanakan pada hari rabu tanggal 20 April 2017 bertempat di STMIK Akakom. Selanjutnya dilakukan koordinasi dengan kedua kelompok mitra yang dilaksanakan pada tanggal 21 April 2017. Kegiatan pertama yang dilakukan adalah pelatihan teknologi tepat guna dalam pembuatan pakan fermentasi (Gambar 2) yang dilakukan dengan durasi waktu lebih kurang 8 hari.

Kegiatan ini diawali dengan pembuatan rumah pakan dengan ukuran $2 \times 4 \mathrm{~m}^{2}$ yang akan digunakan bersama oleh kedua mitra.

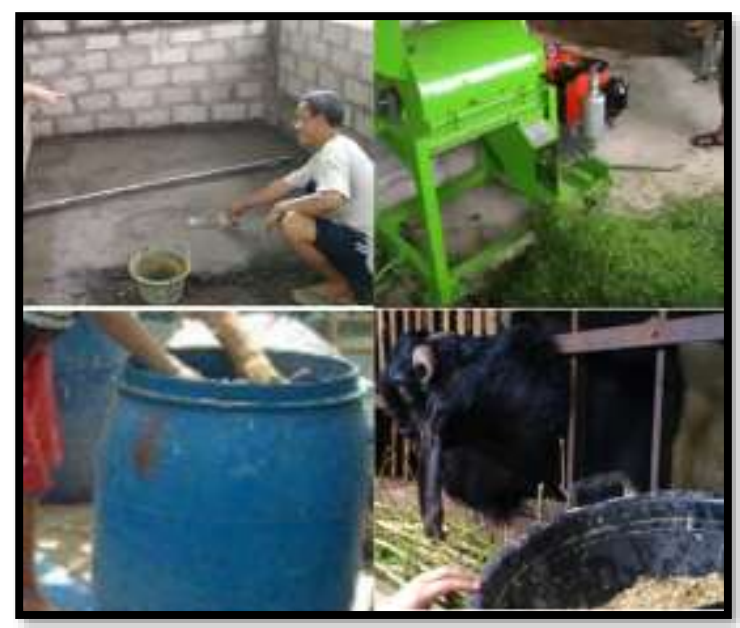

Gambar 2. Proses pakan fermentasi

Kebutuhan dalam pembuatan rumah pakan antara lain material bangunan seperti pasir, semen, urug, split, batako, rangka baja ringan dan atap gavalum. Sedangkan peralatan pendukung adalah chooper (mesin perajang bahan pakan), drum bertutup dan obat pemicu fermentasi.

Proses pengerjaan banguan rumah pakan dilakukan secara gotong royong oleh anggota kelompok kedua mitra selama kurang lebih 6 hari. Setelah rumah pakan siap, selanjutnya adalah pembelian mesin pencacah pakan (chooper), drum sebagai wadah fermentasi pakan dan bahan pembuat pakan termasuk obat fermentasi. Pelatihan pembuatan pakan melibatkan tenaga ahli yang berpengalaman dalam pembuatan pakan fermentasi selama 2 hari. Hari pertama adalah proses pembuatan dan hari ke dua digunakan untuk melihat dan menggunakan (pemberian pakan) hasil fermentasi.
Teknologi fermentasi pakan bisa menjadi pilihan mudah. Alasanya, bahan baku bisa dari berbagai daun dan jenis rumput keing atau limba pengolahan kedelai (menjadi tahu atau tempe). Bisa juga dari gedebok pisang ditambah bekatul. Semua bahan itu dicampur lalu difermentasikan selama minimal $3 \times 24$ jam. Hasilnya adalah makanan ternak fermentasi yang lebih awet dengan bau yang khas dan kandungan karbohidrat, protein dan vitamin yang cukup stabil. Pemberiaan teratur dengan jumlah seimbang antara berat pakan dan berat hewan membuat hewan ternak menjadi terpelihara secara baik.

Fermentasi itu sendiri merupakan proses pemecahan senyawa organik menjadi sederhana yang melibatkan mikroorganisme dengan tujuan menghasilkan suatu produk yang mempunyai kandungan nutrisi, tkestur yang lebih baik memperpanjang masa penyimpanan, mengendalikan pertumbuhan mikroba kontaminan.

Untuk penyiapan pakan ternak ini perlu diberi perlakuan secara biologis dengan mengunakan SOC. SOC merupakan campuran berbagai mikrooragisme yang berguna untuk mempercepat proses pemecahan serat pada pakan ternak, sehingga mudah dicerna oleh ternak. Selain pemberiaan pakan fermentasi di dalam meningkatkan kualitas ternak yang perlu kita lakukan adalah dengan pemberian pakan konsentrat.

\section{Pembuatan pupuk organik}

Pelatihan pembuatan pukuk organik menggunakan kotoran padat (inthil) teranak yang dikumpulkan dari kandang kedua mitra. Untuk menampung dan mengumpulkan kotoran tersebut di buat sebuah tempat permanen, sehingga pengumpulan inthil menjadi lebih rapi dan bersih (Gambar 3).

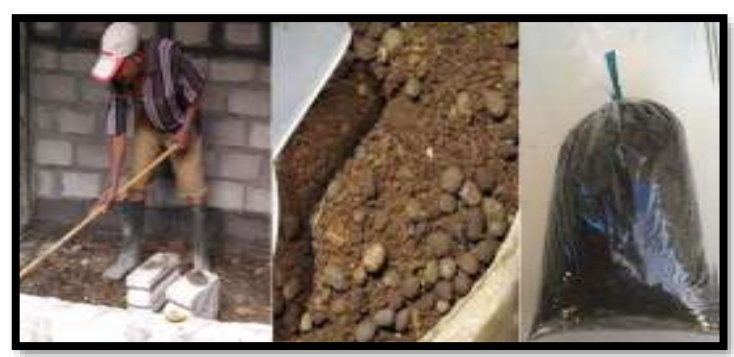

Gambar 3. Pembuatan pupuk kompos

Proses pembuatan tempat pengumpulan inthil dan pelatihan memerlukan waktu pelatihan dila manajemen usaha dan pemasaran akan dilakukan 
pada tahap kedua setelah pelaporan kemajuan kegiatan yang direncanakan selama dua hari. Proses pembuatan pupuk dengan memanfaatkan biostarter.

Biostater yang dapat digunakan untuk pembuatan kompos sudah banyak beredar dimasyarakat dengan bermacam-macam merk dagang dengan dosis dan bahan yang bermacam-macam namun sama dalam hal tujuan yaitu untuk mempercepat proses dekomposisi. Kompos yang dihasilkan mempunyai kualitas yang baik, dosis penggunaan pada tanaman lebih hemat dibanding pupuk kandang tanpa diolah dahulu. Kompos inthil yang dihasilkan memberikan nilai tambah pengusahaan ternak karena memiliki nilai jual yang lebih tinggi dibandingkan tanpa pengomposan. Setelah kompos jadi maka selanjutnya bisa dipakai untuk memupuk tanaman, namun apabila dijual dikemas terlebih dahulu agar kelihatan praktis dan lebih rapi. Tiap kemasan berbeda-beda sesuai dengan permintaan pasar, biasanya bobot kompos tiap kemasan antara lain : $3 \mathrm{~kg}$ (plastik), $5 \mathrm{~kg}$ (plastic), 10 $\mathrm{kg}$ (karung) dan $25 \mathrm{~kg}$ (karung).

\section{Pengolahan susu aneka rasa}

Susu merupakan minuman yang lazim di konsumsi semua orang,karena asupan pertama yang di konsumsi oleh umat manusia adalah susu. Tak jarang juga masa pertumbuhan di waktu kecil identik dengan mengonsumsi susu. bahkan tak sedikit orang yang telah mengonsumsi susu seiring pertumbuhanya hingga umur yang tak terbatas.

Selain menyehatkan, susu juga dapat membantu menjaga kondisi tubuh supaya tetap fit. Untuk saat ini susu di olah menjadi beberapa hidangan, seperti aneka susu aneka rasa ,mie kuah susu, es krim, puding susu dan masih banyak lagi.

Olahan susu yang cukup terkenal saat ini adalah minuman susu aneka rasa,seperti susu rasa strawberry, coklat royal, oreo, tiramisu, milo dan lainlain.Untuk membuat minuman susu aneka rasa yang enak, maka bahan utama berupa susu harus sangat di perhatikan. Sebaikya susu segar yang berasal dari ternak susu perah, misalnya kambing etawa, karena kemurnian susu perah lebih terjaga.

Pada kegiatan ini, pelatihan proses pengolahan susu aneka rasa (Gambar 4) dilakukan selama 1 hari dengan melibatkan anggota kedua kelompok mitra.

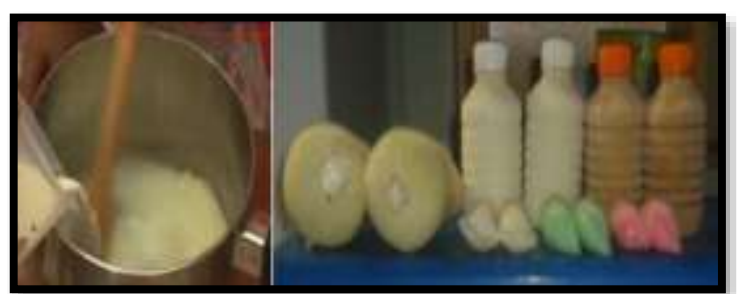

Gambar 4. Pembuatan susu anek rasa

Susu yang diolah didapat dari hasil perahan ternak dari kedua mitra. Hasil pelatihan berupa produk susu segar aneka rasa

\section{Pelatihan perawatan anak kambing etawa yang baru lahir dan pemerahan susu}

Kegiatan selanjutnya yang telahdilaksanakan adalah pelatihan perawatan anak baru lahir dan pemerahan susu (Gambar 5). Guna mendapatkan anak kambing dan susu yang berkualitas perlu diperhatikan teknik pemeliharaan pasca kambing melahirkan.

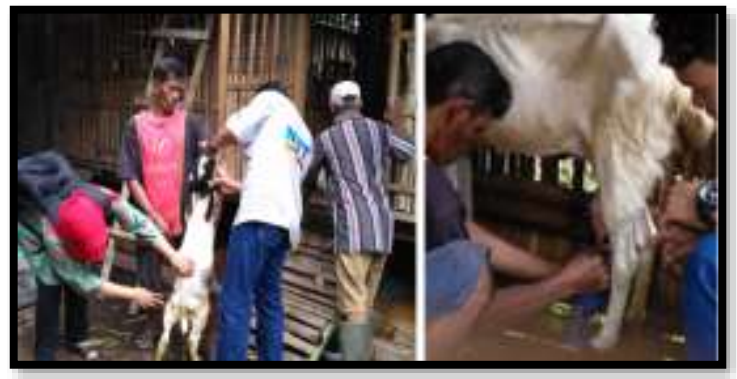

Gambar 5. Pelatihan perawatan anak kambing etawa yang baru lahir dan pemerahan susu

Teknik perawatan anak kambing yang perlu dilakukan yaitu: (1) peternak perlu memperhatikan pertumbuhan anak/cempe agar pertumbuhan sesuai dengan harapan, (2) jika indukan beranak 1 maka pertumbuhan anak akan lebih maksimal kerena susu berlimpah. Jika indukan beranak 2 diperlukan pengawasan agar anakan tidak berebut susu sehingga pertumbuhan menjadi tidak seimbang. Jika beranak 3 maka salah satu cempe bisa menyusu ke induk lain yang beranak 1, (3) jika jumlah susu yang dihasilkan dirasakan kurang maka sangat dianjurkan untuk ditambah dengan susu sapi. Berikan susu dengan dot bayi dengan lubang dot sedikit besar.

Guna memperbanyak susu kambing etawa dapat dilakukan terapi khusus. Ketika kambing masuk usia kebuntingan 4 bulan message/pemijatan 
mulai dilakukan, hal ini dilakukan untuk memperbesar kelenjar dan memperlancar susu.

Pakan tambahan berupa bungkil kedelai mulai diberikan sebanyak 150 gram pagi dan 150 gram sore dicampurkan dengan komboran. Massage dilakukan tiap hari sampai kambing beranak. Setelah beranak bungkil kedelai dinaikkan menjadi 250 gram pagi dan 250 gram sore yang dicampur dengan komboran. Massage tetap dilakukan sampai kirakira 3 minggu setalah kambing melahirkan. Beberapa hal yang perlu diperhatikan dalam pemerahan susu antara lain, (1) pemerahan susu harus rutin dengan pemerahan yang tetap. Lubang tampungan botol yang digunakan harus yang kecil. Susu kambing sangat sensitif terhadap bau sekitar, (2) setelah pemerahan botol harus langsung ditutup, (3) birahi harus dimonitor dengan baik, biasanya kambing birahi setelah 2 bulan beranak dan (4) bila indukan positif bunting, susunya akan mengalami kering pada saat kebuntingan hari ke-105 (3,5 bulan).

\section{Pelatihan manajemen usaha dan penjualan online (e-commerce)}

Pemasaran adalah sistem keseluruhan dari kegiatan usaha yang ditujukan untuk merencanakan, menentukan harga, mempromosikan dan mendistribusikan barang dan jasa yang dapat memuaskan kebutuhan pembeli maupun pembeli potensial. Konsep-konsep inti pemasaran meluputi: kebutuhan, keinginan, permintaan, produksi, utilitas, nilai dan kepuasan; pertukaran, transaksi dan hubungan pasar, pemasaran dan pasar.

Manajemen pemasaran berasal dari dua kata yaitu manajemen dan pemasaran. Pemasaran adalah analisis, perencanaan, implementasi, dan pengendalian dari program-program yang dirancang untuk menciptakan, membangun, dan memelihara pertukaran yang menguntungkan dengan pembeli sasaran untuk mencapai tujuan perusahaan. Sedangakan manajemen adalah proses perencanaan (planning), pengorganisasian (organizing) penggerakan (actuating) dan pengawasan.

Untuk memperlancar pemasaran hasil produksi kelompok mitra, maka diperlukan sebuah sistem yang dapat membantu pemasaran. Selain penyediaan website (Gambar 6), kelompok mitra akan diberikan pelatihan cara penjulan online.

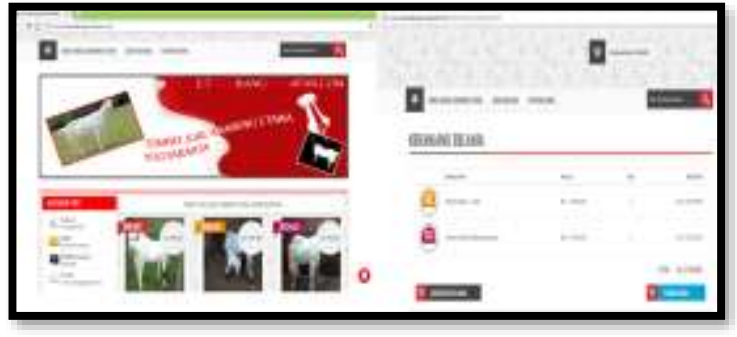

Gambar 6. Aplikasi penjualan online

Sistem yang akan dibuat adalah website penjualan (e-commerce) yang mempunyai bermanfaat antara lain, (1) menampilkan profil usaha kelompok mitra, (2) menampilkan cara budidaya kembing etawa, (3) memanpilkan manfaat susu kambing etawa, (4) mempromosikan penjualan produk kambing etawa, misalnya olahan susu aneka rasa dan (5) memproses pemesanan produk oleh pembeli.

Kegiatan pemgembangan aplikasi e-commerce sudah dilakukan. Proses pembuatan akan memekan waktu kurang lebih 1 bulan. Persiapan yang dilakukan selain proses coding aplikasi adalah dengan penyediaan hosting sebagai tempat penyimpanan dan sewa domain sebagai nama alias untuk dapat mengakses aplikasi yang dikembangkan. Sebagai alternatif nama yang akan digunakan adalah www.etawabanguntapan.com.

\section{KESIMPULAN}

Beberapa kesimpulan yang dapat diambil berdasarkan kegiatan yang telah dilaksanakan antara lain:

1. Penerapan teknologi pakan fermentasi menghasilkan pakan berkualitas dan kelompok mitra tidak lagi kesulitan untuk menyiapakan pakan kambing, terutama ketika musim kemarau.

2. Rumah pakan dan mesin pencacah rumput berguna untuk proses fermentasi, sehingga pakan kambing dapat disimpan dalam waktu yang lebih lama dan memiliki kualitas yang bagus.

3. Pengolahan limbah (kotoran) menjadi pupuk organik dapat menambah pemasukan dan menjaga sanitasi kandang.

4. Pengolahan susu murni menjadi berbagai produk 
olahan susu aneka rasa menjadikan produk lebih bervarisi dan mudah dalam pemasaran.

5. Penanganan anak kambing baru lahir perlu dilakukan untuk mendapatkan anakan yang sehat dan berkualitas baik.

6. Pelatihan manajemen usaha diperlukan untuk meningkatkan keterampilan dalam manajemen usaha dan pencatatan transaksi keuangan.

7. Pemanfaatan website penjualan (e-commerce) sebagai media promosi dapat memeperluas jangkauan pemasaran hasil usaha kelompok.

\section{.5. REFERENSI}

Anoname, 2011, Cara membuat pakan fermentasi, http://www.etawafarm.com/2011/10/ cara-membuat-pakan-fermentasi1.html

Kusuma, $\quad$ B.D., 2012, Kambing Etawa,http://kambingetawa.net/home

Retnaningdiah, 2009, Faktor-faktor yang Mempengaruhi Kualitas Jiwa Kewirausahaan Wanita Nelayan di Kabupaten Bantul,
Prosiding Seminar Nasional hasil Penelitian Dosen Kopertis Wilayah V, Yogyakarta.

Saitul, F., Adrizal, Nelson dan Akmal, 2011, Aplikasi teknologi pelleting pelepah sawit sebagai pakan ternak di sentra peternakan kambing PE kecamatan bajubang kabupaten Batanghari, Jurnal Pengabdian pada Masyarakat, No. 52 Tahun 2011, ISSN: 1410-0770.

Sarwono, B., 2011, Beternak Kambing Unggul, PT. Penebar Swadaya, Jakarta.

Setiawan, T. dan Tanius, 2008, Beternak Kambing Perah Peranakan Etawa, PT. Penebar Swadaya, Jakarta.

Sodiq, A. dan Zainal, A., 2008, Meningkatkan Produksi Susu Kambing Peranakan Etawa, Agromedia Pustaka, Jakarta.

Syambyah dan Handoyo, S.R., 2012, Kiat Sukses Bertenak Kambing Peranakan Etawa, Andi Offset, Yogyakarta.

Zimmerer, T.S., 2008, Kewirausahaan dan Manajemen Usaha Kecil, Salemba Empat, Jakarta. 